Krystyna Tuszyńska, Nina Anna Trzaska

Uniwersytet im. Adama Mickiewicza w Poznaniu

\title{
Teoria Poezji Nieosobistej Thomasa Eliota a Kanon Konstandinosa Kawafisa. Porównanie poglądów i założeń dwóch klasycystów
}

\section{Modernizm - ramy czasowe i ogólna charakterystyka}

Modernizm, będąc okresem literackim, szerzej ujmując - trendem artystycznym, zamyka się zazwyczaj w latach 1855-1935' ${ }^{1}$, choć jego ramy chronologiczne nie są jednoznacznie wytyczone, co uświadamiają znane słowa Williama Butlera Yeatsa: „Things fall apart, the centre cannot hold”'. Sam zaś termin „modernizm” odniesiony do poszczególnych literatur narodowych odnosi się do czasowo dość różnych okresów i często determinuje jakościowo odmienne, przynajmniej pozornie nieporównywalne, zjawiska literackie, niekiedy obejmując rozległe nurty artystyczne, czasami zaś małe grupy literackie (Możejko 30).

Analizując osiągniecia modernizmu jako trendu artystycznego, nie można zapominać o uczonych, jak Zygmunt Freud czy Ernst Mach, oraz o filozofach - Arturze Schopenhauerze, Henryku Bergsonie i Fryderyku Nietzschem,

1 Na temat ram czasowych modernizmu zob. Sheppard 72. Badacz pisze: „Niektórzy [...] krytycy sytuują jego [modernizmu - K. T., N.A.T.] początek nawet w roku 1870, by objąć Nietzschego i Rimbauda, podczas gdy inni, głównie północnoamerykańscy sytuują jego koniec w latach 50-tych, co pozwala objąć wczesne powieści V. Nabokova, późną poezję Carlosa W. Williamsa ,abstrakcyjny ekspresjonizm oraz dzieła stworzone pod wpływem modernistów europejskich, którzy wyemigrowali do USA" (Sheppard 72).

2 „Rzeczy się rozpadają, środek nie wytrzymuje”. Słowa Yeatsa za: Możejko 28. 
prądy literackie bowiem nie rodzą się i nie rozwijają w hermetycznym naczyniu, lecz korzystają one ze zdobyczy nauki i kierunków filozoficznych epoki i współzależą od nich. Pierwsza obszerna praca Freuda, otwierająca badania metodą psychoanalizy, Studia nad histeria (Studien über Hysterie), powstała w 1885 roku jeszcze we współpracy z Josephem Breuerem. Z kolei Mach w The Science of Mechanics (1883) postawił podstawowe tezy empiriokrytycyzmu, uznającego psychologiczną naturę wrażeń, co przeszło do nauki jako „teoria czystego doświadczenia”. Za sprawą filozofii Nietzschego zakwestionowane zostały wsporniki metafizyczne i wiara w boski porządek rządzący światem, jak też zasadność istnienia Boga ${ }^{3}$, a filozofia Bergsona odebrała niezachwianą władzę rozumowi, stawiając $w$ jego miejsce, $w$ procesie poznania, intuicję jako uświadomiony pęd naturalny. Jak się zdaje, wpływ Bergsona na literaturę był nawet silniejszy, ponieważ bez wypracowanego przez niego pojęcia jaźni głębokiej nie mógłby pojawić się strumień świadomości (stream of consciousness) jako jedna $\mathrm{z}$ typowych technik literackich modernizmu ${ }^{4}$. Bergson uświadomił swoim czytelnikom i słuchaczom wykładów w Collège de France różnicę między naukowym podejściem do czasu a jego subiektywnym doświadczaniem przez człowieka. Stąd jego niepomierny wpływ na pisarzy posługujących się strumieniem świadomości, Marcela Prousta, Wirginię Wolf, poetów, jak Thomas Eliot w poemacie The Love Songs of J. Alfred Prufrock. Ponadto poczucie bezsensu i pustki jako wyniku traumatycznych doświadczeń I wojny światowej, nazwanej Wielką Wojną, potem epidemie nawiedzające Europę: epidemia dżumy i grypy „hiszpanki”, wzmacniały pesymizm tego okresu, brak akceptacji dla dotychczas

3 Nietzsche odpowiedzialny jest za pesymizm, który przejął po Arturze Schopenhauerze, z tą różnicą, że Schopenhauer dostrzegał ratunek w sztuce, podczas gdy dla Nietzschego jedyną wartością stało się samo życie jako biologiczne istnienie jednostek silnych, stawiających sobie wysokie cele i dążących do nich „poza dobrem i złem”. Stąd nastąpiło w filozofii Nietzschego „przewartościowanie wszystkich wartości”, to znaczy wartości moralnych wyznawanych w Europie od czasów filozofii Sokratesa i Platona, wzmocnionych przez chrześcijaństwo oraz demokrację, jak: dobro, altruizm, współczucie dla jednostek słabych i potrzeba moralna niesienia im pomocy, wspólny wszystkim podział dóbr itp. Zostały one potępione przez Nietzschego jako znamię słabości ducha.

4 Pojęcie strumienia świadomości, stream of consciousness pojawia się w pracy Jamesa. The Principles of Psychology uważane są za przełomowy tekst na polu psychologii. James dostrzegł „luki” i płynność doznań psychicznych człowieka i stąd zaproponował pojęcie strumienia świadomości, uznając, że metaforami na określenie ludzkiej świadomości mogą być terminy „rzeka”, „strumień”, które wskazują na typową dla niej właściwość przepływu. W 1918 roku termin ten został zastosowany w kontekście dzieła literackiego (powieści Doroty Richardson) przez Maya Sinclaira. 
wyznawanych wartości tak moralnych, jak - szerzej - duchowych, kwestionowanie istnienia Boga jako odniesienia metafizycznego w podejmowanych przez jednostkę ludzką działaniach, utratę wiary w wyższość kultury Zachodu, co pociągnęło za sobą zwracanie się ku innych kulturom, zwłaszcza ku orientalnemu mistycyzmowi, przykrojonemu jednak na miarę człowieka Zachodu.

Celem artykułu jest przede wszystkim wskazanie na spójność poglądów jednego z prawodawców poetyki modernistycznej, Thomasa Eliota, i najbardziej rozpoznawalnego poety Grecji nowożytnej, Konstandinosa Kawafisa, urodzonego i mieszkającego w greckiej diasporze w Aleksandrii ${ }^{5}$, ale także próba dowiedzenia, iż Aleksandryjczyk mógł wyprzedzić o kilkanaście lat postulaty literackie wyartykułowane przez Eliota. Pozwala na to analiza wybranych utworów z Kanonu ${ }^{6}$ Kawafisa i lektura jego Ars Poetica, czyli zbioru szkiców literackich w języku angielskim, niepublikowanych za życia poety. Dostrzeżone analogie między przesłaniem literackim esejów Eliota a praktyką poetycką Kawafisa oraz luźnymi myślami zanotowanymi w Ars Poetica dowodzą wspólnego obu artystom sposobu postrzegania rzeczywistości literackiej, niezwykłego daru oglądu „natury poezji”.

Przy stosunkowo łatwym wyjaśnieniu nazwy prądu „modernizm”, trudności przysparza wydestylowanie cech unifikacyjnych z różnorodności trendów literackich, jakie rozwinęły się w łonie modernizmu, a tym samym stworzenie satysfakcjonującej definicji tegoż prądu'. Sam termin „modernizm”, zaczerpnięty

5 Poezje Konstandinosa Kawafisa doczekały się w Polsce kilku przekładów: Zygmunta Kubiaka, Jacka Hajduka, Antoniego Libery i (część wierszy) Nikosa Chadzinikolau, Michała Bzinkowskiego, Janusza Strasburgera. Można uznać to za niezaprzeczalny dowód wartości i ponadczasowości poezji Kawafisa.

6 O Kanonie Kawafisa więcej przy charakterystyce jego poezji. Jorgos Seferis, grecki laureat Literackiej Nagrody Nobla (1963), uznał, że Kawafis uporczywie pracował nad swoją drogą jako poeta, odrzucając utarte zwroty, banały, wielosłowność, dzięki czemu znalazł własną formę ekspresji (zob. Kubiak 76-77).

7 Możejko uważa za najlepszą książkę wyjaśniającą ten termin pracę Astradura Eysteinssona The Concept of Modernism, opartą na solidnym materiale dowodowym i uwzględniającą różne możliwe interpretacje terminu „modernizm”. Pluralistyczny charakter sztuki końca xIx i pierwszej połowy xx wieku generuje niespotykaną wielokierunkowość.

8 Wysiłki w tym kierunku były powszechnie podejmowane przez badaczy literatury w latach sześćdziesiątych i siedemdziesiątych xx wieku, jednak nie zostały ukoronowane jednolitą i syntetyczną definicją. Uczeni mawiają: „Modernizm jest tematem niemożliwym" w sensie wyartykułowania jego definicji oraz znalezienia wspólnego mianownika dla sposobów reagowania przez artystów na fin de siècle, upadek lub przynajmniej znalezienie się na rozdrożu kultury Zachodu. O typach odpowiedzi na 
z języka łacińskiego, od przymiotnika modernus - 'nowy, nowoczesny' - prowokuje pytanie o istotę nowoczesności. Implikuje bowiem nieustanną kreatywność artysty z jednej strony, a z drugiej - konieczność wyrażania tradycyjnych/ znanych tematów w nowy/nowoczesny sposób, ponieważ nowoczesność jest usytuowana zawsze wobec czegoś, co nie jest już nowe. W „modernizacji” twórczości literackiej widzieć należy zakłócanie tematów należących do tradycji przez nowy, „modernistyczny” sposób wyrazu, ale też rozszerzenie tematyki literackiej o tematy, które stanowily dotąd tabu lub przynajmniej traktowane były marginalnie. Do „technicznych” z kolei nowości należą: odrzucenie wszechwiedzącego narratora, zaadaptowanie „porządku mitologicznego”, posłużenie się strumieniem świadomości, zakwestionowanie zasady decorum ${ }^{9}$, proponowanie stylu wypowiedzi, który faworyzuje bogactwo wyobraźni, skrótowość w wyrażaniu myśli oraz wiersz wolny. Nowa tematyka wiązała się zaś z traumatycznymi doświadczeniami Wielkiej Wojny, powstaniem miasta-giganta, w tym reakcją na industrializację i gwałtowną urbanizację, ze sprzeciwem wobec „ponumerowania” społeczeństwa i rodzącej się niechęci wobec indywiduów niepoddających się zaszufladkowaniu, wręcz niechęci ogółu wobec jednostek odmiennych. Modernizm jest nie tylko nowym sposobem zamanifestowania rozdźwięku między konserwatywną, humanistyczną wrażliwością a coraz bardziej niehumanistycznym światem, lecz implikuje konieczność rozwinięcia nowej konceptualizacji świata, w której pojawia się nieprzejrzystość podmiotu literackiego dla niego samego, co prowadzi - w skrócie myślowym - do problematyzacji tego, co realne (Wawrzyszko 142-143). W centrum rozważań nad nową wrażliwością, „modernistyczną”, stoi kryzys pojmowania podmiotowości, uznawanie dotychczasowego modelu podmiotowości tylko za jedną z możliwych realizacji, co streszczało się w powiedzeniu Artura Rimbauda „JE est un autre" ${ }^{10}$. Kolejnym wyzwaniem stojącym przed nową wrażliwością jest alienacja człowieka, której sprzyja zakwestionowanie wiodącej roli intelektu, adekwatności języka w odsłanianiu rzeczywistości, zafałszowanie obrazu czasu, który do tej pory cieszył się przywilejem teleologicznego punktu dojścia. W wielu obszarach ludzkiej aktywności: w naukach ścisłych, psychologii,

pesymizm „czasów nowoczesnych” / modernizującej się rzeczywistości zob. Sheppard 123-140.

9 Zasada decorum sformułowana została przez Arystotelesa w postaci prepon, „tego, co stosowne" w Retoryce, powtórzona przez Horacego w Liście do Pizonów w odniesieniu do literatury. W retoryce rzymskiej odpowiednikiem prepon było aptum.

10 Słowa z wiersza Arthura Rimbauda List do widzacego, dedykowanego Paulowi Demeny’emu, napisanego 15 maja 1871 roku. 
filozofii, religii (ta najsilniej zmierzała ku kryzysowi) rzeczywistość staje się bardziej skomplikowana niż rzeczywistość wyjaśniona przez fizykę Newtona i geometrię Euklidesa. Naukowcy muszą przystać na coś, co nieznane, a artyści równolegle - tworzyć teksty, które przez swoją formę i treść będą szokowały odbiorcę. Artyści specjalnie manifestowali swoją odmienność i rezygnowali z odbiorcy masowego, co zdaniem współczesnego myśliciela, José Ortegi y Gasseta $^{11}$, prowadziło do dehumanizacji nowoczesnej sztuki i literatury, gdyż ta nie była rozumiana i aprobowana przez szerokiego odbiorcę. W ślad za tym szły inne cechy nowoczesnej sztuki: ironia i skrajny subiektywizm. Kawafis należy do tych poetów, którzy na warsztat literacki wzięli tematy tabu, w jego przypadku była to miłość homoseksualna, i równocześnie wyposażali utwory poetyckie w subtelnie dawkowaną ironię oraz subiektywny ogląd rzeczy, mimo iż przesłanie tej poezji można uznać za uniwersalne.

Trudności, jak wspomnieliśmy, przysparza stworzenie jednej wspólnej definicji tego okresu artystycznego, która obejmowałaby wszystkie jego trendy, to znaczy „-izmy”, jak estetyzm, symbolizm, akmeizm, ekspresjonizm, imaginizm, dadaizm, futuryzm, surrealizm, kubizm i inne. Niemniej jednak próbowano znaleźć słowa klucze przydatne w kompleksowej definicji. Należą do nich: bezkompromisowy intelektualizm, element dionizyjski, uczucie alienacji i izolacji, zagrożenie chaosem powiązane ze skłonnością do badań naukowych, specyficzna ironia wynikająca z konfliktu między ego a światem (Sheppard 73). Pomimo iż żadna strategia w definiowaniu modernizmu nie okazała się skuteczna, formułowano definicje, gdyż bez nich niemożliwe staje się badanie okresu artystycznego, w tym literackiego. Należy mocno zaakcentować, że pytanie o naturę modernizmu jest jednym z najtrudniejszych pytań w historii literatury. Zasadniczo modernizm jako prąd kulturowy rozwija się w dwóch kierunkach, które oscylują wokół różnych założeń artystycznych: klasycyzmu i awangardy ${ }^{12}$. Prezentowany artykuł skupia się na klasycyzmie, gdyż ten jest wyborem greckiego poety Kawafisa.

José Ortega y Gasset był mistrzem i animatorem ruchu umysłowego w Hiszpanii, począwszy od trzeciej dekady xx wieku, występując w przełomowym momencie historii - powolnego konania jednej epoki, której był spadkobiercą, by patronować ruchom awangardowym w literaturze. Dehumanizacja sztuki (La deshumanisacion del arte) ukazała się w 1925 roku. Kierując się niechęcią do dziewiętnastowiecznego realizmu, Ortega zacieśnia problematykę literatury do zagadnień techniki, stylu i ruchliwej gry ironii, jednak nie pomija wartości kultury, która zapewnia trwałość i witalność ludzkim wysiłkom.

12 W zasadzie mianem „awangardy” zwykło określać się w różnych okresach literackich te trendy, które mają charakter eksperymentalny i stanowią niejako forpocztę trendu 


\section{Pojęcie klasycyzmu i klasycyzująca twórczość Kawafisa}

Początkowo na Zachodzie posługiwano się w praktyce terminem „modernizm” dla określenia literatury eksperymentalnej, raczej umiarkowanie liczącej się z tradycją, zaś termin „awangarda” odnosił się do skrajnych eksperymentów artystycznych, które zrywały z dziedzictwem przeszłości (Możejko 36). Z biegiem lat pojawił się trzeci termin - „klasycyzm” - dla nazwania nurtu artystycznego o charakterze bardziej „zachowawczym”, opartym na dialogu z przeszłością, i zaczęto zastępować nim modernizm w mniej nowoczesnym wydaniu. Thomas Eliot i inni anglosascy krytycy literaccy proponowali już wcześniej nazwę „klasycyzm", jednak ostatecznie, w wyniku analizy transformacji założeń artystycznych i praktyki literackiej przełomu sztuki, uznano za bardziej odpowiedni termin „modernizm” (Możejko 37). Dzięki temu modernizm zaczął funkcjonować jako nazwa długotrwałej, choć wewnętrznie zróżnicowanej epoki artystycznej opartej na swoistej dychotomii między nowoczesnym klasycyzmem, zapatrzonym w tradycję, a awangardą, gardzącą tradycją. Wobec wielu wymienionych nurtów w łonie modernizmu Eliot opowiedział się po stronie artystów, którym towarzyszy w „zmodernizowanej” twórczości szacunek wobec tradycji śródziemnomorskiej, wobec poetów i pisarzy greckich i rzymskich, nie tylko tych wielkich, ale też pomniejszych. Był jednak świadom praw artystycznych drugiego obozu - awangardy, zrywającej z tradycją i zachłyśniętej nowoczesnością.

Skoro zarówno Eliot, jak i Kawafis opowiedzieli się po stronie „unowocześnionej tradycji”, zwróćmy uwagę na cechy klasycyzującego modernizmu w kontekście twórczości Kawafisa. Modernizm klasycyzujący, mając charakter bardziej zachowawczy, stoi poniekąd w opozycji do dehumanizacji kultury europejskiej. Dla Eliota klasycyzm był środkiem zapobiegawczym i ostrzeżeniem przed postępującą dezintegracją współczesnej cywilizacji Zachodu. Edward Możejko, zestawiając różne sposoby postrzegania klasycyzmu, przywołuje opinię rosyjskiego poety, Osipa Mandelsztama, który nazwał klasycyzm „nostalgią za kulturą świata”, zaś polski poeta, Czesław Miłosz, określił dojrzały modernizm „literaturą karmioną przez literaturę” (Możejko 38). Jak w bardzo celnym, aforystycznym sformułowaniu Miłosza brzmią nuty bliskie koncepcji Eliota, tak u Mandelsztama klasycyzm jawi się raczej jako zaranie nowych czasów ${ }^{13}$.

artystycznego. O charakterystyce awangardy modernistycznej i pytaniu, czy objąć ją terminem „modernizm”, zob. Eyteisson 155-199.

13 Możejko przytacza jedną z wypowiedzi Mandelsztama w swoim przekładzie: „Dzisiejsi poeci mówią językiem wszystkich czasów i wszystkich kultur. Wszystko jest możliwe. Tak jak pokój umierającego jest otwarty dla wszystkich, tak otwarte są drzwi starego świata [...]. Wszystko jest osiągalne: wszystkie labirynty, tajemnice, zakazane przejścia” (Możejko 38, cytat z eseju Mandelsztama Słowo i kultura, 1971). 
Kawafisa należy uznać za poetę podążającego drogą wskazaną później chronologicznie w esejach Eliota, to znaczy drogą klasycyzmu. Poeta grecki sam daleki był od przypisywania się do jakiegokolwiek współczesnego trendu artystycznego, ale jego odmienność i nowoczesność w uprawianiu poezji doprowadziła do tego, że założyciel i animator ruchu futurystycznego, a więc awangardy, Filippo Tomasso Marinetti podczas spotkania z nim w Aleksandrii uznał go za poetę futurystycznego ${ }^{14}$. Nowoczesność Kawafisa, zwłaszcza na tle innych poetów greckich, polegała zarówno na zabiegach technicznych, jak i na wejściu swoją twórczością do zakazanego świata miłości homoseksualnej. Kawafis uczynił to jednak ostrożnie, stosując maski w poezji - jawne JA, połączone z formami gramatycznymi, które określają płeć i osobę będącą przedmiotem uczuć, pojawia się u Kawafisa rzadko i późno, bo po 1917 roku (Youncenar 8o) i umieszczając swoich bohaterów zazwyczaj w odległej przeszłości. Przeszłość tę budował świat śródziemnomorski, przede wszystkim zaś ulubiona przez poetę epoka hellenistyczna z jej upodobaniem do miłości homoseksualnej i do krótkiej, wyrafinowanej formy literackiego epigramatu. Znajdując swoje własne miejsce „poza czasem teraźniejszym”, Kawafis uniknął pułapki fin de siècle z jej destrukcyjną siłą ${ }^{15}$. Marguerite Youncenar (Youncenar 89) trafnie porównała czas w poezji Kawafisa do czasu z paradoksów szkoły eleackiej, na przykład paradoksu strzały, która równocześnie wypuszczona z łuku przemierza swój tor, ale zarazem stoi w miejscu ${ }^{16}$. Poeta mieszka (w czasie teraźniejszym)

14 „We wrześniu 1929 roku Kawafisa odwiedził w Aleksandrii Marinetti, już wówczas sławny inicjator futuryzmu, sam też urodzony w Aleksandrii. O rozmowie obu poetów pisały lokalne gazety. Marinetti uznał, iż mimo że Kawafis nadal używa przecinków, kropek i czasowników, a przy tym brzydzi się zdobyczami techniki [Kawafis nigdy nie założył w swoim mieszkaniu w Aleksandrii oświetlenia elektrycznego, wybrał świeczniki i lampy naftowe - K.T., N.A.T.], to jednak jego myśli są uniwersalne, zerwał z łzawym romantyzmem xIx w. i wyprzedza swój czas w sztuce, a to wystarczy, aby nazwać go futurystą. Kawafis podziękował Marinettiemu za wspaniałą koncepcję, jaka streszcza się w słowach: 'Każdy, kto wyprzedza swój czas w sztuce albo w życiu, jest futurystą, jednak grzecznie zaprzeczył jej” (Kubiak 72-73).

15 O destrukcyjnej sile „zmierzchu człowieka Zachodu” oraz dziewięciu drogach ucieczki znad przepaści zob. Sheppard 123-134. Sheppard wyróżnia dziewięć odpowiedzi; najbardziej nihilistyczne, polegające na przekonaniu, że zbliża się apokaliptyczny koniec, po którym nastąpi „bezkresna ciemność, prowadziły artystów przełomu kultury do samobójstwa lub szaleństwa. Autor dostrzega trzy odpowiedzi proklamujące bezkrytyczne zaangażowanie w „nowy świat” (włoski futuryzm, wczesny wortycyzm, modernistów reakcyjnych).

16 Szkoła eleacka zasłynęła z paradoksów, między innymi paradoksu strzały czy Achillesa, który nigdy nie dogoni żółwia. Paradoksy te tłumaczy „dyskretna koncepcja czasu”, 
w przeszłości i dzięki temu znajduje miejsca w czasie i przestrzeni (świata śródziemnomorskiego) wolne od wątpliwości, jakie niesie nowoczesność.

Kawafis, należąc do grona klasycyzujących modernistów ceniących tradycję kulturową, jest przywiązany do znaczenia słowa. Wprawdzie dostrzega jego wieloznaczność i pewien rodzaj destabilizacji, jednak - jako klasycyzujący modernista - wykorzystuje greckie mity, motywy filozoficzne i religijne, a tym samym pielęgnuje obraz poety-erudyty. Równocześnie wszystkie wspomniane elementy konfrontuje ze współczesnością, pyta o sens ludzkiej egzystencji, poddaje je zarówno własnemu intelektualnemu przewartościowaniu, jak i formalnemu przetworzeniu ${ }^{17}$. Dzięki temu poezja reprezentowana przez Kawafisa z jednej strony zyskuje głębię filozoficzną, z drugiej - pozwala artyście na dystans wobec słowa.

Kawafis sam podzielił swoje dzieło, określane dalej jako Kanon, na trzy grupy: wiersze historyczne, filozoficzne i hedonistyczne, zwane obecnie eroty$\mathrm{kami}^{18}$. Utwory historyczne, czerpiące z tradycji śródziemnomorskiej, zazwyczaj ewokują złożoną refleksję filozoficzną. Pokazują nieuniknione przeznaczenie, na ogół tragiczne, albo nieznośną samotność człowieka, nieobcą mentalności fin de siècle. Kawafis, czerpiąc tematy z historii greckiej i darząc szczególną estymą epokę hellenistyczną ${ }^{19}$, opowiada się niejako za współczesnym także jemu kosmopolitycznym charakterem Aleksandrii. Kosmopolityzm był cechą dystynktywną Aleksandrii od czasów założenia jej przez Aleksandra Wielkiego w 332 roku p.n.e. ${ }^{20}$ Kawafis, zapatrzony w miniony splendor miasta, dumny jest

zakładająca, że czas składa się z liniowo ułożonych, odrębnych punktów. Stąd strzała wypuszczona z łuku w każdym momencie stoi w bezruchu, a żółw zawsze wyprzedza szybkonogiego Achillesa.

17 Te cechy klasycyzującego modernizmu wymienia Możejko (Możejko 39). Nietrudno odnieść je do twórczości Kawafisa.

18 Są to wiersze o silnym piętnie doświadczenia zmysłowego, a jednocześnie odległe od jakiejkolwiek przesady miłosnego liryzmu, a także dalekie od typowego wydźwięku słowa „erotyzm”.

19 O upodobaniach historycznych Kawafisa: Kubiak 22, 8o-84, zob. też Youncenar 66. Czasy homeryckie posłużyły jako inspiracja dla kilku zaledwie wierszy, Grecja klasyczna również jest słabo reprezentowana, a Rzym - widziany oczami greckimi.

20 Według artykułu Alaina Vérona Pollutant lead reveals the pre-Hellenistic occupation and ancien growth of Alexandria, Egypt (2006) i jego współpracowników z Uniwersytetu Paula Cézanne’a miasto o nazwie Rhakotis istniało w tym miejscu już w $2686 \mathrm{r}$. p.n.e. Nie odbiera to jednak Aleksandrowi Wielkiemu tytułu do sławy budowniczego Aleksandrii, który zaszczepił w mieście helleńskiego ducha. 
ze swego aleksandryjskiego pochodzenia, co pięknie ilustrują wersy z wiersza Dla Ammonisa, zmarłego w wieku 29 lat, w roku 610:
Rafaelu, [...]
Ma to być bardzo kunsztowne. Napiszesz tak, jak trzeba.
Twoja greka jest zawsze piękna i melodyjna.
Dziś nam jednak potrzeba pełni twojego mistrzostwa, [...]
Chodzi o to, żeby twoje wersy - rozumiesz Rafaelu -
Miały w sobie coś z naszego życia. I rytm, i każda fraza
Niech będą takie, by wszyscy czytając, wiedzieli,
Że to Aleksandryjczyk o Aleksandryjczyku pisze (Kawafis 77).

Także forma literacka uprawiana w epoce aleksandryjskiej (hellenistycznej), a mianowicie krótka forma epigramatyczna, stała się ulubionym wzorem Kawafisa. Skoro w czasach poety Aleksandria straciła dawną renomę ośrodka hellenizmu, sięga on do epoki hellenistycznej lub bizantyńskiej, kiedy miasto cieszyło się uprzywilejowaną pozycją w świecie kultury ${ }^{21}$. Humanizm, a co za tym idzie, obcowanie z tradycją u Kawafisa jest różne od tego europejskiego. Dla niego humanizm ma źródło w pełnej blasku Aleksandrii kosmopolitycznego świata, zaś my, Europejczycy, wychowani na kulturze grecko-rzymskiej, upatrujemy humanizmu w białych murach Akropolu i rzymskim Panteonie (Youncenar 66). Kawafis, portretując „starą Aleksandrię”, zabiera czytelnika do określonej przestrzeni: na ulice, do sklepów, kawiarni, tawern, ale w wąskiej przestrzeni fizycznej jednocześnie czytelnik gości w rozległej, dzięki wspomnieniom i pamięci, przestrzeni czasowej.

Współczesność, jeśli pojawia się w twórczości Kawafisa, to jedynie za sprawą stosowania metafor o charakterze historiozoficznym. Świat poetycki Kawafisa pozostaje na wskroś grecki, ukazany przez obrazy historyczne i historyczne portrety. Często problematyka zaczerpnięta z przeszłości odgrywa rolę poetyckiej maski dla wyrażenia uniwersalnej, ogólnoludzkiej prawdy, a niekiedy - gorącego uczucia. Poeta posługuje się materiałem zaczerpniętym z tradycji śródziemnomorskiej w celu uchwycenia stanów emocjonalnych człowieka w ogóle, człowieka jako takiego, człowieka współczesnego. Ta korespondencja między przeszłością a dniem dzisiejszym prowadzi często autora wierszy ku tragicznym konkluzjom, ale trzeba podkreślić, że w poezji tej po-

21 Sentyment do Aleksandrii widać też w tytułach wierszy poety, dość wspomnieć kilka: Kupiec aleksandryjski; Miris. Aleksandria 340 po Chr.; W Aleksandrii, 31 p.n.e.; Królowie aleksandryjscy i in. 
rażka jednostki przekuwa się w zwycięstwo obiektywnych wartości, takich jak godność, świadomość wypełnienia obowiązku zgodnie z poczuciem honoru, dostojeństwo, dobrze pojęta duma. Principia te, dzięki głębokiej refleksyjności Aleksandryjczyka, współegzystują z klimatem fin de siècle, podszytym ironią i pesymizmem.

Zilustrujmy powyższe stwierdzenie kilkoma przykładami: jednym z nich jest utwór Chodź, królu Lacedemończyków, który opowiada o tym, jak matka króla Sparty Kleomenesa III, Krateziklea, kobieta o silnym charakterze, kroczy ze swoim synem, jeszcze królem, z godnością i w milczeniu ku nieuchronnemu przeznaczeniu, świadoma, iż zmierzają ku spotkaniu ze śmiercią. Idzie nie okazując emocji, ale gdy w świątyni Posejdona znajdują się na chwilę sami, mówi do syna:

„Chodź, królu Lacedemończyków!

Kiedy wyjdziemy ze świątyni,

Niechże nikt nas nie zobaczy płaczących

Albo czyniących cokolwiek, co byłoby niegodne Sparty,

Tylko to jedno od nas zależy;

A dola będzie taka, jak bogowie dadzą”.

I weszła na okręt, ku owemu „dadzą” (Kawafis 169).

Z relacji znajdującej się u Plutarcha ${ }^{22}$, która mogła stanowić inspirację dla poety, wiemy, że król Sparty popełnił w Egipcie samobójstwo, Krateziklea została zaś stracona wraz ze swoimi wnukami, następcami tronu, patrząc najpierw na ich śmierć. Historyk, moralista i filozof, jakim był Plutarch, powiada, że król Sparty był głęboko poruszony i bardzo przygnębiony w drodze na statek, ale jego dostojna matka stanowiła dlań oparcie. Postawa Krateziklei została uwieczniona w wierszu Kawafisa. Narracja ma źródła historyczne, ale sposób interpretacji faktów w wykreowanym przez poetę świecie daje nadzieję na istnienie niezbywalnych wartości mimo pesymizmu nieuchronnego finału.

Plutarch, Żywot Kleomenesa. Kleomenes był synem Leonidasa II, kontynuatorem wielkich reform społeczeństwa spartańskiego. Po odniesieniu dwóch wielkich zwycięstw nad Związkiem Achajskim dokonał zamachu stanu, znosząc urząd efora i geruzję (radę starców), przepędził 80 oligarchów, umorzył długi, przeprowadził podział gruntów, przywrócił staro-spartańskie wychowanie. Dążył do hegemonii Sparty i pozyskał wiele miast-państw, jednak w 221 roku p.n.e. został pokonany przez stratega Związku Achajskiego, Aratosa, sprzymierzonego z królem macedońskim Antygonosem Dosonem. Wówczas uszedł do Egiptu, a w 219 roku p.n.e. odebrał sobie życie. Wówczas władca Egiptu, Ptolemeusz, rozkazał wykonać egzekucję na jego dzieciach i matce. 
Wybór honorowej śmierci pojawia się w wierszu Termopile, związanym tematycznie ze sławną obroną wąwozu Termopile przez trzystu Spartan. Wydarzenie miało miejsce w 480 roku p.n.e. i zostało przekazane przez dziejopisa Herodota (Dzieje, ks. vII, 213). W wyniku zdrady Efialtesa Termopile ostatecznie zdobyli Persowie i droga do Grecji stała przed zwycięzcami otworem. Ludzie dla Herodota, podobnie jak dla Kawafisa, są odpowiedzialni za swoje czyny, dające o nich świadectwo moralne. Ostateczny osąd wydaje przyszłość. Dla Kawafisa pochwała Leonidasa jest rezultatem dokonanego przez niego moralnego wyboru. Wybór ten ma tym większą wagę, że Leonidas mógł przewidzieć przyszłość, jaka czeka jego i trzystu jego towarzyszy, ale trwał na posterunku i walczył do końca.

Cała waga poematu zawarta została w czterech ostatnich wersach:

I jeszcze większej pochwały są godni, Jeżeli przewidują (a wielu to przewiduje),

Że ostatecznie pojawi się Efialtes

I że Medowie, w końcu przejdą (Kawafis 13) ${ }^{23}$.

Kawafis dodatkowo wzbogaca tematykę historyczną przez interesującą grę interpunkcji, powtórzeń i zdań nawiasowych. W cytowanym wyżej wierszu postawił najistotniejszą dla jego wymowy myśl w nawiasie (a wielu przewiduje).

W utworze Ci, co walczyli za Związek Achajski pojawia się ten sam motyw gloryfikacja mężczyzn, którzy walczą na przyjętej pozycji, mimo iż może okazać się ona stracona, ludzi, którzy nie zmieniają frontu w obliczu zagrożenia czy niepewnego scenariusza zakończenia. Ostatnie słowa utworu brzmią: „ «Takich mężów wydaje nasz naród» - powiedzą / O was. Tak cudowna będzie wasza chwała” (Kawafis 122). Opowiedziane wydarzenie miało miejsce w 146 r. p.n.e., kiedy Grecy ostatecznie utracili niepodległość, a ich ojczyzna stała się prowincją rzymską.

Trzy krótko zaprezentowane wiersze egzemplifikują Kawafisowy świat tradycji z jego własnym systemem wartości, które nie ulegają destabilizacji czy zniweczeniu za sprawą pesymizmu nowoczesności. Przeszłość staje się dla poety enklawą.

Zgodnie $\mathrm{z}$ obowiązującą w modernizmie perspektywą miasta jako tła poezji Kawafis spaceruje po Aleksandrii w wielu jej odsłonach, w „czasie odnalezionym” dzięki wspomnieniu czy trawestacji historii. Figura miasta odgrywała w modernizmie, niezależnie od jego zasadniczego trendu, klasycyzującego bądź awangardowego, bardzo istotną rolę w twórczości artystów ${ }^{24}$.

23 „Medowie” to greckie określenie na Persów.

24 Twórczość Charlesa Baudelaire’a związana była z Paryżem, Thomasa Eliota z Londynem, Jamesa Joyce’a z Dublinem, Bolesława Prusa z Warszawą. 
Modernistyczne miasto jako efekt rozwoju przemysłu i postępującej urbanizacji stało się niejako "nowym bytem” (Hajduk 22), naturalnym środowiskiem, w którym egzystowały wielkie masy ludzkie na niespotykaną do tej pory skalę. Wprawdzie Aleksandria, w której mieszkał Kawafis, była o wiele uboższa od wielkich miast europejskich, a nawet wyludniona w wyniku burz historycznych, jakie przetoczyły się przez Bliski Wschód (okupacja Aleksandrii, potem protektorat brytyjski, klęska Wielkiej Idei i masowe przesiedlenie ludności greckiej z obszarów Bliskiego Wschodu, gdzie Grecy żyli od tysiącleci), jednak dla niego, dzięki jej ponadczasowości, stawała się na kartach poezji miastem tętniącym życiem.

W badaniach nad figurą miasta zwraca się uwagę, że miasto nabiera charakteru labiryntu, którego przemierzanie staje się celem samym w sobie (Hajduk 23). Tak też jest z poezją Konstandinosa Kawafisa, z tym że Kawafis każdorazowo „stwarza swoją Aleksandrię, jak pisze w wierszu z 1929 roku W tej samej przestrzeni: „Ja ciebie utworzyłem (gr. se demiourgisa) w radości i smutku, / Z tyloma zdarzeniami, z tyloma sprawami" (Kawafis 167) ${ }^{25}$.

Jest przywiązany do swojego miasta, kocha je, a jednak miłość ta miewa gorzkawy posmak. Kocha „ruch na ulicach i w sklepach” ${ }^{26}$, w kawiarniach i restauracjach łowi słowa potrzebne jego poezji, czasami nawet niepoprawne gramatycznie, wypływające, jak mówi, „z ust małych dzieci i pijaków” (Kubiak 68), a przez to autentyczne. Sam posługiwał się językiem wytwornym w prostocie, $\mathrm{z}$ umiejętnością meandrycznego rozwijania tematu, igrania słowami i dystansowania się od nich. Jeden z jego rozmówców, przyjaciel i krytyk, Timos Malanos, zanotował o nim takie słowa: „[... ] może po raz pierwszy posługiwał się naszym językiem współczesny Grek ze sztuką i wdziękiem rozmówców starożytnych" (Ouranis 22, przeł. K.T.). Aleksandria Kawafisa, stworzona przez niego, podsłuchana i podpatrzona, ale też wyczytana $\mathrm{z}$ historii miasta, jest Aleksandrią tyleż geograficzną, co historyczną, ale w sensie - rozciągniętą na tysiąclecia. Jest ponadczasowa, a zarazem żywa. Nie jest symbolem, poeta nie nadaje jej żadnego uproszczonego sensu. Jest chrześcijańska i pogańska, jest wielobarwna i przemawia licznymi głosami, w których znajdujemy odcienie uczuć: osamotnienia, smutku, radości, dumy, matni (Tuszyńska 43-45). Poeta przemierza co dzień tę Aleksandrię w słomkowym kapeluszu, z rękami w kieszeniach (Kubiak 62), przystając przed witrynami sklepów, trwoniąc w ten sposób czas i uosabiając flâneura (Hajduk 24), który, z początkowo pejoratywnego odcienia „,jednostki wyjętej poza nawias społeczny" w II połowie XIX wieku przyjął znaczenie

25 O poezji-Mieście u Kawafisa zob. Tuszyńska 21-47.

26 Wiersz Wieczorem z 1917 roku (Kawafis 76). 
„Człowieka trwoniącego czas przed witryną sklepową" ${ }^{27}$. Status tego wielkomiejskiego włóczęgi wyznacza samotność w tłumie (Hajduk 26), jednak miasto nie przytłacza go, nie męczy, a nawet jeśli jest chwilowo zmęczony czy zniechęcony, powraca na ulice, przed witryny sklepów, do tawern i kawiarni. Z miasta czerpie siłę witalną i staje się jego obserwatorem. Urbanizm Kawafisa z rolą miasta Aleksandrii - w kluczowym punkcie perspektywy jego poezji realizuje postulat sformułowany później przez Samuela Becketta, iż „poezja powinna być czymś, a nie o czymś” (Kubiak 174). Można podsumować te rozważania stwierdzeniem, iż Kawafis jako klasycyzujący poeta był prorokiem nowych czasów. Sam uważał się za poetę hiper-modernistycznego, poetę przyszłych pokoleń, ale „zakochanego w poprawnej frazie, świadczącej o naturalnym arystokratyzmie”, operującego „stylem lakonicznym, ale zrównoważonym”, poetę, który swoją twórczością „przypadnie do smaku przyszłym pokoleniom, rozbudzonym coraz to nowymi osiągnięciami naukowymi i ożywionym subtelnością mechanizmu intelektualnego" (Kubiak 74).

Powyższe rozważania prowadzą do konkluzji, że Kawafis już w najbardziej powierzchniowej warstwie swojej twórczości wpisuje się w idee Eliota odnośnie do reinterpretacji i „zakłócania” europejskiej kultury, której korzeni amerykańsko-brytyjski poeta upatruje w Grecji, Rzymie i Izraelu ${ }^{28}$. Jego rozumienie tradycji, przytoczone w eseju Tradycja i talent indywidualny (1919) ${ }^{29}$, opiera się głównie na percepcji historycznej, która niejako konstytuuje twórcę i pozwala mu na świadome uplasowanie się przestrzeni czasowej:

Odziedziczyć jej [tradycji - K.T., N.A.T.] po prostu nie można, jeśli zaś chce się ją posiąść, można to zrobić tylko z dużym wysiłkiem. Warunkiem jej jest zmysł historyczny, który wypada uznać wprost za niezbędny dla każdego, kto by chciał pozostać nadal poetą po ukoń-

27 Hajduk przytacza definicję flâneura autorstwa Charlesa Baudelaire’a: „Obserwator, dyletant, flâneur - nazwijcie go, jak chcecie, żeby jednak scharakteryzować tego artystę, trzeba go obdarzyć epitetem, którego niepodobna zastosować do malarza tematów wiecznych lub przynajmniej bardziej trwałych, bohaterskich czy religijnych. Niekiedy jest poetą, częściej zbliża się do powieściopisarza czy moralisty; jest malarzem okoliczności i tego, co w niej wieczne" (cyt. za Hajduk 25). Hajduk zaznacza, że Baudelaire był jednym $z$ duchowych przewodników Kawafisa.

28 Trzykrotnie jest to wspomniane w eseju Jedność kultury europejskiej (1946) (Eliot 249-264).

29 Esej Eliota Tradition and Individual Talent został po raz pierwszy opublikowany w „The Egoist” w 1919 roku, a następnie, w 1920 przedrukowany w pierwszej książce Thomasa Eliota na temat krytyki literackiej, The Sacred Wood. 
czeniu lat dwudziestu pięciu; a zmysł historyczny wymaga rozumienia przeszłości istniejącej nie tylko w przeszłości, lecz i w teraźniejszości; zmysł historyczny wymaga od autora nie tylko tego, żeby w kościach czuł swoją współczesność, ale odczucia, że całość literatury europejskiej, od Homera począwszy, i wraz z nią również literatura ojczysta istnieją jednocześnie i składają się na ład współistniejący. Taki zmysł historyczny, który jest odczuciem tego, co ponadczasowe, i tego, co przemijające oraz ponadczasowe i przemijające zarazem, rozstrzyga o tradycjonalizmie pisarza. I jednocześnie czyni on pisarza najbardziej świadomym swego miejsca w czasie i własnej swojej współczesności (Eliot 1998: 25).

Nie oznacza to jednakże negacji nowoczesności czy odrzucenia eksperymentów artystycznych w imię korzystania jedynie z uznanych historycznie technik i gatunków literackich. Twórca powinien być świadomy zarówno swojej kultury, jak i aktualnego położenia, powinien balansować na cienkiej linie teraźniejszości rozciągniętej między znaną przeszłością a nieznaną przyszłością. Współczesną sobie historię Eliot określił w eseju „Ulisses”, porządek i mit (1923) jako „bezgraniczną panoramę ulotności i bezładu” (Eliot 1970: 45), którą należy kontrolować, porządkować, kształtować i nasycać znaczeniem, co umożliwia właśnie nabyta perspektywa historyczna. Podsumowując: przeszłość, owszem, powinna być zastąpiona przez współczesność, ale w takich granicach, w jakich współczesność jest wytyczana przez przeszłość.

\section{Koncepcja poetycka. Ars Poetica a Theory of Impersonal Poetry}

Po zestawieniu problematyki wierszy Kawafisa z pojmowaniem klasycyzmu przez Eliota należy przeniknąć do głębszej warstwy koncepcyjnej w twórczości obu pisarzy. Jest to wyjątkowo trudne zadanie ze względu na rażącą dysproporcję pomiędzy ich pracami czysto teoretycznymi - Eliot napisał bardzo wiele esejów krytyczno-ideowych, natomiast Kawafis, poza kilkoma notatkami, zostawił po sobie bardzo skromne - w polskim przekładzie liczące jedynie siedem stron (Kubiak 238-244) - vademecum znane jako Ars Poetica.

Zważywszy na znaczną objętość dzieła teoretycznego Eliota, odnotujmy, że jego poglądy były przełomowe dla co najmniej kilku wielkich prądów - dla wspomnianych klasycystów oraz dla teorii literatury dziś charakteryzowanej jako formalizm amerykański, a niegdyś jako Nowa Krytyka (New Criticism) ${ }^{30}$. 
Jednocześnie, nie możemy uznać, że uwagi Eliota były tożsame z postulatami tych grup, ale powinniśmy zwrócić uwagę na płynność i stopniową ewolucję myśli amerykańsko-brytyjskiego poety ${ }^{31}$, co zresztą podkreślał on sam w eseju O krytyku krytycznie z 1961 roku $^{32}$. Na samym początku Conclusion (po polsku: Zadania poezji), ostatniego rozdziału książki The Use of Poetry And The Use of Criticism (1933), twierdzi (niejako przekornie), że nie posiada własnej teorii poetyckiej (Eliot 1998: 52). Na polu krytyki literackiej Eliot sam siebie postrzegał jako krytyka, którego działalność krytyczna jest jedynie produktem ubocznym działalności twórczej (Eliot 1998: 7-8).

Z powodu znacznego rozproszenia myśli Eliota bardziej logicznym posunięciem zdaje się przyjęcie za podstawę niniejszej części artykułu syntetycznej koncepcji Kawafisa i skonfrontowanie jej poszczególnych postulatów i konkretnych założeń z teorią amerykańsko-brytyjskiego poety.

W 1903 roku Kawafis sporządził zbiór notatek w języku angielskim, stosując sobie tylko znane skróty dwóch, rzadko trzech sylab, nieprzeznaczony do druku, a jedynie dla osobistego użytku, jako podręcznik sztuki pisarskiej. Zbiór tych notatek, wytyczających drogi poetyckie Kawafisa, został odnaleziony w papierach, jakie poeta pozostawił swemu przyjacielowi, Aleksandrowi Sengonopoulosowi, a opublikowany dopiero w 1963 roku przez Michalisa Petridisa, który nadał mu tytuł nawiązujący do Arystotelesa - Ars Poetica. Jako całość tekst ten stanowi jasny testament poety, ma charakter dyrektywny. Jest to pierwszy utwór Kawafisa pisany prozą, w którym autor w sposób systematyzujący traktuje wytyczne dla uprawiania sztuki poetyckiej i odnosi je do swojej twórczości i swojej roli jako poety (Anton 85-109). Ars Poetica składa się z dwóch części, teoretycznej i przykładowo-praktycznej.

Część pierwsza opisuje kontrole filozoficzną, jakiej poddane zostać powinno dzieło po pracy korekcyjnej. Celem tego zabiegu jest eliminacja niedoskonałości utworu. Kawafis wprowadza w tekście kategorię doświadczenia osobistego ${ }^{33}$, które nie powinno mieć jednakże charakteru absolutnego, jako że domysł również

31 Jest to zresztą niezwykle podobne do treści notatki nr xıv Kawafisa z 1906 roku, w której ukazuje ulotność zasady szczerości w sztuce - dezaktualizacja poglądów sprawia, że wraz z upływem czasu zmienia się stosunek poety do swojego dzieła (notatka w: Kubiak 252).

32 Zgodnie z życzeniem twórcy sformułowanym we wspomnianym eseju przy każdym wspominanym w artykule tekście Eliota będzie podawany rok jego powstania.

33 Dokładny cytat: „Doświadczenie osobiste jest niewątpliwie pożyteczne. Ale gdyby się ściśle przestrzegało granic takiego doświadczenia, okropnie zacieśniłoby się twórczość poetycką, a nawet twórczość filozoficzną. Gdyby trzeba było czekać starości, aby się ośmielić o niej mówić, albo ciężkiej choroby, aby móc o niej wspomnieć, gdyby trzeba 
stanowi ważne narzędzie artystyczne, kreując doświadczenie przypuszczalne. Z obu kategorii należy korzystać rozważnie i wprawnie, jako że stany emocjonalne cechuje ambiwalencja. Często utwór poety ma niedostatecznie określony sens i myśli mogą zostać dopiero powiększone przez czytelników. Poety jako artysty nie powinno kusić przeświadczenie o „absolutnej bezwartościowości wszelkiego dążenia i wewnętrznej sprzeczności każdego przejawu człowieczeństwa”. Powinnością, bez względu na wyznawaną filozofię, jest zaś praca, której produktem są rzeczy piękne. Dzieło artysty nie jest daremne, jeśli wyklucza się jednostkę, a bierze się pod uwagę jego ogólnoludzki wymiar. Powracając do tematu doświadczenia osobistego, to może mieć ono charakter wtórny, jeśli poeta wnika w doznania innych ludzi. Wiersze, będąc zapisem prawdy krótkotrwałej, mają, za pomocą ewokowania stanów emocjonalnych, trafiać do doświadczeń osobistych czytelnika. Druga część Ars Poetica opiera się na praktycznej aplikacji kontroli filozoficznej na przestrzeni dwóch konkretnych wersów.

Już pobieżna analiza ujawnia podobieństwo pomiędzy notatkami Kawafisa a tak zwaną Teoria Poezji Nieosobistej (Theory of Impersonal Poetry) Eliota przedstawioną w opublikowanym szesnaście lat później eseju Tradycja i talent indywidualny (1919). Dla Eliota akt tworzenia jest procesem depersonalizacji artysty $^{34}$. Dojrzałego poetę postrzega jako medium, przez które tradycja przepływa i staje się na nowo „wypracowana”. Porównuje poetę do katalizatora w reakcji chemicznej, w której pierwiastkami wchodzącymi w reakcję są uczucia i emocje, podlegające syntezie, w wyniku której powstaje dzieło literackie. Dzieło to niejako „chwyta” i przekazuje te same uczucia i emocje. Umysł poety jest czynnikiem koniecznym dla twórczości literackiej, ale pozostaje on nietknięty w trakcie wyniku procesu twórczego, bowiem artysta, przetwarzając własny stan emocjonalny, w zasadzie tworzy nowe, całkiem niespodziewane kombinacje i to one stanowią ostateczny produkt kreacji twórczej. To, co nadaje wielkość dziełu, to nie osobiste przeżycia emocjonalne poety, ale raczej charakter procesu tworzenia, w trakcie którego dochodzi do syntezy uczuć i emocji. Poeta jest odpowiedzialny tylko za „ciśnienie”, by tak rzec, którego wynikiem jest wspomniana fuzja. I to właśnie intensywność tej fuzji decyduje o wielkości sztuki. Poeta jest zdepersonifikowanym „pojemnikiem”, odpowiedzialnym za przyjęcie i przechowanie niezliczonych uczuć, fraz, obrazów, aż wszystkie owe cząstki razem zdolne będą stworzyć nowe związki. To Eliot ma na myśli, nazywając

było samemu doznać udręki albo zamętu umysłu, aby je ująć w słowa, przekonalibyśmy się, że do napisania pozostaje zaiste niewiele" (Kubiak 238).

34 Jeszcze dobitniejszy termin śmierci autora pada przy akademickim opracowaniu formalizmu amerykańskiego w: Burzyńska, Markowski 137. 
poetę „medium” 35 . Uczciwa krytyka i wrażliwe uznanie skierowane są nie na poetę, ale na poezję, jak komentuje tę teorię Allen Tate (Tate 284).

W ramach podsumowania należy stwierdzić, że w oba teksty teoretyczne, Ars Poetica Kawafisa i Tradycje i talent indywidualny Eliota, wpisane jest założenie o zdolności twórczości artystycznej do wykraczania poza jednostkowe doświadczenie twórcy, które to powinno być jedynie punktem wyjściowym w konstrukcji bardziej złożonych i potencjalnie prawdopodobnych stanów emocjonalnych. Oznacza to, że jako odbiorcy nie powinniśmy podmiotu lirycznego utożsamiać z autorem i spodziewać się ścisłego biografizmu w twórczości poetyckiej. Przytoczmy dla porównania w tym miejscu cytat z wiersza Tajniki Kawafisa: „Niech z czegokolwiek, com mówił i czynił, / Nikt nie próbuje odczytać, kim byłem" (Kawafis 252) oraz anegdotyczny fragment eseju Eliota Szekspir i stoicyzm Seneki (1927):

Przyznaję, że moje własne doświadczenie jako poety niższej rangi zrobiło mnie może zgorzkniałym sceptykiem: otóż nieznani moi entuzjastyczni wielbiciele nadają moim skromnym utworom znaczenie o kosmicznej rozległości, o którym nigdy mi się nie śniło; i wmawiają mi również, że to, co sam brałem poważnie, ma zakrój wierszy salonowych, i klecą moje osobiste dzieje na podstawie urywków, które albo zaczerpnąłem z książek, albo wymyśliłem z głowy dlatego, że dobrze brzmiały; i nie dostrzegają nigdy autobiografizmu w tym, co rzeczywiście swoją podstawę miało w moich osobistych przeżyciach (Eliot 1998: 100).

Poeta zatem kreuje jeden z możliwych stanów umysłu, ale czytelnik może „rozciągnąć” przekazane treści na osobiste doświadczenia, a tym samym wzbogacić twórczość samego poety. Kawafis niejako dedykuje swe dzieło potomności. Mawiał o sobie, że jest „poetą hipernowoczesnym, poetą przyszłych pokoleń” (Kubiak 73).

\section{Styl Kawafisa a poglądy estetyczne Eliota}

Problematyczną kwestią jest zbadanie podobieństwa w zakresie stylu obu pisarzy. Porównanie poezji Eliota i Kawafisa zostało już dokonane w eseju

35 Znaczące są tu słowa: „[...] im doskonalszy artysta, tym ściślej oddziela się w nim człowiek cierpiący od umysłu twórczego i tym doskonalej myśl przetrawia i przerabia wzruszenia, które służą jej za tworzywo" (Eliot 1998: 29). 
Cavafy and Eliot - A Comparison (Seferis 119-162). Żeby nie powtarzać tego, co zostało już napisane, skupmy się na skonfrontowaniu charakterystycznych cech poezji Aleksandryjczyka z poglądami estetycznymi Eliota, publikowanymi w jego esejach.

Poezja Kawafisa wyróżnia się na tle swoich czasów za sprawą wyeliminowania zewnętrznych atrybutów poetyckości, jakimi są tradycyjne formy metryczne, regularny rytm, rym, metafora, epitet czy klasyczne chwyty retoryczne. Antypoetyckość formy w brawurowy sposób zbliżyła jego poezję do prozy, a najważniejszymi poetyckimi zabiegami stały się oszczędne i precyzyjne operowanie słowem, kreowanie patosu skrajnej lakoniczności, intensyfikacja, dramatyzacja i humanizacja treści, wykorzystywanie wieloznaczności, symboli, sugestii psychologicznych i etycznych ${ }^{36}$. Twórczość Aleksandryjczyka zdecydowanie opiera się na czasowniku, przymiotniki występują sporadycznie i bardzo często mają ogólny, niezdefiniowany charakter. Wiele wierszy Kawafisa jest krótkich (co wydaje się być spadkiem po epigramatach Antologii Palatyńskiej), poeta nie stroni również od białego wiersza.

Styl poezji Kawafisa był zjawiskiem zupełnie nowym w literaturze greckiej. Jego poezja wywoływała mieszane uczucia, miała fanatycznych zwolenników i zajadłych przeciwników (Strasburger 57). Kostis Palamas, niejako rywal Kawafisa, określił jego wiersze jako „zapiski, które nie mogą lub nie raczą być wierszami... reportaże z głębi wieków” (Chadzinikolau 1985: 90), co miało podkreślać antypoetyckość pisarza ${ }^{37}$.

Oczywiście, nie wszystkie cechy typowe dla twórczości Kawafisa zostały wspomniane w esejach Eliota, ponieważ jego pisma krytyczne dotyczą kwestii czysto teoretycznych i ogólnych lub odnoszą się do innych pisarzy niż Aleksandryjczyk. Przede wszystkim przykuwa uwagę fakt, że zarzucane Kawafisowi przez greckich krytyków nieaprobujących jego poetyki mało wyszukane słownictwo i brak obecności epitetów znajduje zrozumienie u Eliota przekonanego, iż poezja powinna mieć związek z językiem potocznym. W eseju Muzyka poezji (1942) czytamy:

36 Opinia za Januszem Strasburgerem (56-57). Zwracamy uwagę, że jest to adnotacja zbiorcza - w Kanonie pojawiają się pojedyncze wiersze operujące poszczególnymi środkami (np. wiersze rymowane - np. Mury, wiersze rytmiczne - metrum Kawafisa był jamb, wiersze $\mathrm{w}$ tradycyjnej formie metrycznej - np. wiersz Tajniki reprezentuje sonet).

37 Kawafis nie pozostał mu dłużny i, czyniąc aluzję do poetów ze szkoły Palamasa (Palamas „panował” nad literaturą grecką około 50 lat), wykrzykiwał histerycznie: „To romantycy! Romantycy! Romantycy!” (Vitti 292). 
Niezależnie od tego, czy [poezja - K.T., N.A.T.] jest przyciskowa czy sylabiczna, rymowana czy nie rymowana, konwencjonalna czy wolna nigdy nie może sobie pozwolić na utratę związków ze stale zmieniającym się językiem codziennego obcowania (Eliot 1998: 38).

Kawafisowa gra słowem (polegająca na wykorzystaniu subtelnego odcienia semantycznego pozornie banalnego, pospolitego wyrazu oraz operowanie syntaksą) przystaje natomiast do Eliotowskiej koncepcji „aluzyjności” zaprezentowanej w eseju Muzyka poezji (1942). Polega ona na tym, że poeta powinien świadomie dobierać słowa i zdawać sobie sprawę z całego spektrum ich konotacji, a następnie, za pomocą właściwego, wyważonego układu wyrazów sprawić, że słowa mniej i bardziej bogate treściowo będą wzajemnie się uzupełniać. Dalej, zarzut niepoetyckości Kawafisa upada w obliczu poglądu Eliota sformułowanego w eseju Kim jest dla mnie Dante (1950): „Nauczyłem się, że zawód poety polega w istocie na zamienianiu tego, co niepoetyckie, w poezje" (Eliot 1998: 89). Wreszcie, w cytowanym eseju możemy również odnaleźć zaobserwowaną u Kawafisa relację pomiędzy tradycyjnymi formami (na przykład epigramami) a wierszem białym. Eliot jest zdania, że należy znaleźć równowagę pomiędzy innowacją a tradycją tak w słownictwie, jak i w stylistyce oraz formie. Użycie form regularnych w opinii Eliota wiąże się ze stałą potrzebą twórcy, którą można porównać do naturalnej potrzeby powtarzalności refrenu czy partii chóralnej $\mathrm{w}$ popularnej piosence. Jednocześnie $\mathrm{w}$ korzystaniu $\mathrm{z}$ dawno ustanowionych form istnieje wielka pokusa ucieczki w zdezaktualizowany styl, co stanowi udział niekompetentnych twórców. Eliot podkreśla, że nie chodzi o nagięcie się poety do wybranej formy, ale przeciwnie - o zmuszenie formy do wyrażenia przekazu (Eliot 1998: 49). Jeśli zaś chodzi o wiersz wolny, to dla dobrego poety żaden wiersz nie jest „wolny” - tylko zły poeta może uznać go za wyzwolenie od formy. Eliot postrzega go jako bunt przeciwko formom martwym i przygotowanie, formę pośrednią $\mathrm{w}$ stosunku do form nowych lub restauracji form dawnych (Eliot 1998: 49). Kawafis, jak już zaznaczono, czyni zaś z obu form solidny użytek artystyczny, co wskazuje na jego ogromną świadomość twórczą.

\section{Cechy poety i elementy procesu twórczego}

W wypracowaniu stylu poetyckiego niewątpliwie istotną rolę pełni sam przebieg procesu twórczego oraz samoświadomość twórcy. Tutaj należy zwrócić uwagę na dwie kwestie, które, co prawda, nie wpasowują się ani w świat wykreowany, ani w koncepcję, ani w styl dzieła, jednakże dotyczą twórcy i pośrednio wpływają na jego pracę. Wyróżniamy je, ponieważ są w jaskrawy sposób widoczne 
już przy pierwszej styczności z każdym z omawianych pisarzy. Chodzi tutaj o dojrzałość twórczą oraz o miejsce poety w spektrum wieszcz - rzemieślnik.

Konstandinos Kawafis bez wątpienia zasługuje na miano „poety wieku dojrzałego” bądź wręcz „poety starości”. Wiemy, że selekcja jego wierszy była wyjątkowo surowa - jego „idealna książka”, Kanon, obejmuje jedynie sto pięćdziesiąt cztery wiersze (jeden z nich znalazł się w nim niejako bezprawnie - dołączył go do zbioru nie autor, a wydawca). Twórca uznał się za odpowiedzialnego poetę dopiero w 1911 roku, w wieku czterdziestu siedmiu lat. Pośród kanonu tylko dwadzieścia cztery wiersze są określane jako pro tou 1911 („przed 1911”), wszystkie pozostałe są napisane później. Szacuje się, że przed ową przełomową datą napisał około dwustu pięćdziesięciu wierszy, z których dużą część zniszczył, a część zachował w swoich szufladach (Kubiak 57-58). Sam poeta tak pisze o swojej wczesnej twórczości w notatce z 1906 roku:

Odkładając, ciągle odkładając publikowanie, jakże wiele zyskałem!

Pomyśleć o tych... śmieciach (w wieku lat 25, 26, 27 i 28), o wierszach bizantyńskich i wielu innych, które by mnie teraz hańbiły.

Ileż zyskałem!

A wszystkie te wiersze napisane między 19 a 22. Cóż za okropne śmiecie! (Kubiak 13-14)

Wyjaśnienie takiego ogromu samokrytycyzmu zachowało się w wypowiedzi poety zanotowanej przez Georgiosa Lechonitisa, w której Kawafis ujawnia, że potrzebuje czasu na twórcze przetworzenie własnych doświadczeńn ${ }^{38}$.

Na koniec zwróćmy uwagę na przesłanie jednego z najpopularniejszych wierszy Kawafisa, Itaki - wędrówka do tytułowej Itaki winna być „długa”, „pełna przygód i doświadczeń”, wypełniona doznaniami zmysłowymi i nauką. Ważne, by „podróż trwała wiele lat”, aby w momencie dotarcia „stary” podróżnik, „bogaty” w doświadczenia i „mądry” nie oczekiwał nic od Itaki i zrozumiał jej prawdziwą naturę (Kawafis 40-41).

Eliot podchodzi do dojrzałości twórczej w sposób podobny do aleksandryjskiego poety - w swojej twórczości krytycznej wielokrotnie podejmuje ten temat. Miał świadomość własnego twórczego dojrzewania i płynności poglądów, co ujawnił w eseju O krytyku krytycznie (1961), w którym niejako żali

38 Dokładny cytat: „Na ogół było tak, że wielcy pisarze i poeci pisali najlepsze swoje utwory w młodości, pisali je, zanim nadeszła starość. Ja zaś jestem poetą starości. Fakty, choćby najżywsze, nie dają mi natchnienia od razu. Musi przedtem upłynąć pewien czas. Dopiero później, wtedy gdy je wspominam, inspirują mnie” (Kubiak 57-58). 
się, że jego młodzieńcze poglądy cytuje się na równi z obecnymi, bez brania pod uwagę stopniowych zmian zachodzących w jego procesie myślowym. Przy całej zmienności poglądów Eliota temat dojrzałości twórczej jest podejmowany w bardzo synkretyczny sposób. W Zadaniach poezji (1933) Eliot przyznaje, że niejako kusi go zakończenie książki chwytem retorycznym: „Hiperbolicznie powiedzieć by można, że poeta jest starszy od wszystkich ludzi” (Eliot 1998: 62). Kwestia dojrzałości jest istotna również w eseju Kto to jest klasyk? (1944), gdzie Eliot stosuje termin „dojrzałość” jako najbardziej pokrywający się semantycznie w jego opinii z określeniem „klasyk” ${ }^{39}$. W dalszej części wykazuje, że chodzi nie tylko o dojrzałość indywidualną twórcy, ale również o dojrzałość jego otoczenia (stopień zaawansowania jego cywilizacji, języka etc.). Samego słowa „dojrzałość” nie da się natomiast według niego zdefiniować, jest to coś po prostu wyczuwalnego dla dojrzałego odbiorcy dopiero w momencie kontaktu z danym człowiekiem, literaturą, cywilizacją. Proces dojrzewania twórczego jest odmienny dla każdego umysłu. Twórca dojrzały powinien mieć świadomość zarówno swoich poprzedników, jak i oryginalności własnego pokolenia. O ile nie możemy dziś wypowiedzieć się definitywnie na temat dojrzałości języka i cywilizacji Aleksandrii w czasach Kawafisa (zwłaszcza że pisał w języku niejako dla siebie obcym ${ }^{40}$ ), to bez wątpienia wyważone balansowanie pomiędzy tradycją a innowacją pasuje jak ulał do jego literackiej sylwetki.

Wieloletni proces twórczy Kawafisa wiąże się z jeszcze jednym aspektem. Autor zapisał się w historii poezji raczej jako homo faber niż homo vates (Chadzinikolau 1985: 94). Kawafis jest „rzemieślnikiem słowa”. Przyjrzyjmy się bliżej jego metodologii - Jorgos Seferis w wywiadzie do „Paris Review” z 1970 roku stwierdził, że najbardziej ceni u Kawafisa wieloletnią pracę nad utworami w jego opinii Aleksandryjczyk do trzydziestego czwartego roku życia pisał bardzo złą poezję, którą „poprzez odrzucanie” (czyli usuwanie z tekstu wszystkich niepotrzebnych elementów) stopniowo doskonalił, dzięki czemu osiągnął swój styl i kunszt (Chadzinikolau 1985: 77). Sam Aleksandryjczyk twierdził, że nie czuje natychmiastowej weny i musi minąć czas, zanim wydarzenia z przeszłości go zainspirują ${ }^{41}$.

39 Dokładny cytat: „Jeśli istnieje słowo fundamentalne, wyrażające maksimum tego, co rozumiem przez termin «klasyk», to będzie nim słowo «dojrzałość»" (Eliot 1998: 66).

40 Kawafis posługiwał się niestandardowym językiem greckim (czyli nie należącym ani do języka mówionego, tzw. dimotiki, ani do języka archaizującego, tj. katharevusy), który możemy określić jako fuzję panujących tendencji językowych w Grecji właściwej. Kawafis niejako stworzył swój własny język poetycki. Więcej o połączeniu dimotiki i katharevusy zob. Vitti 291.

41 Zob: przypis 38. 
Eliot wypowiedział się na ten temat w tekście Zadania poezji (1933) (Eliot 1998: 53). Oddziela w nim poezję jako produkt długotrwałej pracy intelektualnej od metafizycznego doświadczenia, jakim jest „wieszczenie”. Nie szuka natchnienia w transie, inspiracją jest raczej obraz wynurzający się we wnętrzu pamięci poety -niczym Wenus Anadyomene (Eliot 1998: 55) - opracowany za pomocą odpowiednich słów. W eseju Kim jest dla mnie Dante (1950) Eliot opisuje niedościgłego Dantego (którego poezja, jak deklaruje, wywarła największy wpływ na jego własną twórczość) jako właśnie rzemieślnika. W Szekspir i stoicyzm Seneki (1927) podkreśla, że „poeta uprawia poezję, metafizycy uprawiają metafizykę” (Eliot 1998: 111), co sugeruje rozdzielność elementu transcendentalnego od poezji. W końcu, w eseju Czterech dramaturgów elżbietańskich (1924) porównuje akt tworzenia sztuki do prozaicznych zadań typu wytoczenie dzbanka.

\section{Zakończenie}

Celem artykułu było wskazanie na zbieżność Eliotowskiej koncepcji poezji w postaci klasycyzującego modernizmu z poglądami na sztukę poetycką, wdrożonymi we własną twórczość aleksandryjskiego, a zatem należącego do greckiej diaspory, poety Konstandinosa Kawafisa. Za warte podkreślenia uważamy dwa fakty: 1. Kawafis w teorii i w praktyce wyprzedził chronologicznie postulaty Eliota; 2. Kawafis jest najchętniej czytanym i tłumaczonym poetą współczesnej Grecji ze względu na zdolność przekazania treści ważnych dla „nowoczesnego" człowieka za pomocą historycznych metafor i portretów. Co więcej, należy dodać, że obaj greccy laureaci Literackiej Nagrody Nobla, Jorgos Seferis (1963) i Odisseas Elitis (1979) zdobyli uznanie i głębokie zrozumienie w oczach współczesnych krytyków oraz czytelników, ponieważ odwoływali się w swojej twórczości do tradycyjnych wartości ludzkich, których korzeni trzeba szukać w greckiej historii. Elitis, udzielając wywiadu prasowego po odebraniu Nagrody Nobla, wyznał: „Gdybym nie był Grekiem, zapewne nie byłbym poetą” (Chadzinikolau 2004: 126). Pisarz angielski, Edward Morgan Forster, który poznał osobiście Kawafisa w Aleksandrii podczas I wojny światowej i prowadził z poetą długie rozmowy na temat sztuki, wróciwszy w 1919 roku do Anglii, urzeczony jego poezją, zainteresował nią Eliota. Ten zaś jako redaktor od 1922 roku czasopisma literackiego „Criterion” zapragnął wydać wiersze Kawafisa w przekładzie Jorgosa Wasalopoulosa. Nie doszło jednak do tego, Kawafis nie był entuzjastą tych tłumaczeń, poza tym nie uważał jeszcze swojej „idealnej księgi” za gotową. Skończyło się na publikacji zaledwie kilku wierszy w różnych periodykach angielskich.

Kawafis i Eliot nigdy nie zetknęli się bezpośrednio za życia. 


\section{| Bibliografia}

Anton, John P. „C.P. Cavafy's Ars Poetica”. Philosophy and Literature 1 (1978). S. 85-109.

Burzyńska Anna, Markowski Michał Paweł. Teorie literatury xx wieku. Podręcznik. Kraków: Znak, 2007.

Chadzinikolau, Nikos. Historia literatury nowogreckiej 1453-1983. Warszawa-Poznań: Wydawnictwo Naukowe PwN, 1985.

Chadzinikolau, Nikos. Odisseas Elitis, poeta światła i morza. Poznań: Wydawnictwo Naukowe UAM, 2004.

Eliot, Thomas. „Ulisses. Porządek i mit”. Przeł. Stanisław Barańczak. Nurt 5 (1970). S. 44-46.

Eliot, Thomas. Kto to jest klasyk i inne eseje. Przeł. Maciej Żurowski, Helena Pręczkowska, Magdalena Heydel, Maria Niemojowska. Kraków: Znak, 1998. Eyteisson, Astradur. „Awangarda jako/czy modernizm?”. Przeł. Dorota Wojda. Odkrywanie modernizmu. Przekłady i komentarze. Red. R. Nycz. Kraków: Universitas, 2004. S. 155-199.

Hajduk, Jacek. Kawafis. Świat poetycki. Kraków: Homini, 2013.

Kawafis, Konstandinos. Wiersze zebrane. Przeł. Zygmunt Kubiak. Warszawa: Tenten, 1995.

Kubiak, Zygmunt. Kawafis Aleksandryjczyk. Warszawa: Tenten, 1995.

Możejko, Edward. „Modernizm literacki: niejasność terminu i dychotomia kierunku". Teksty Drugie 5/6 (1994). S. 26-45.

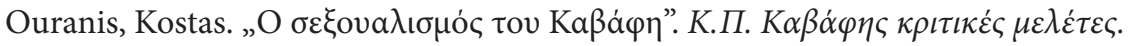

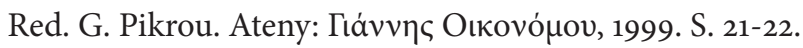

Seferis, George. „Cavafy and Eliot - A Comparison”. Przeł. Rex Warner, Th. Frangopoulos. On the Greek Style: Selected Essays in Poetry and Hellenism. Boston: Little, Brown, and Company, 1966. S. 119-162.

Sheppard, Richard. „Problematyka modernizmu europejskiego”. Przeł. Paweł Wawrzyszko. Odkrywanie modernizmu. Przekłady i komentarze. Red. R. Nycz. Kraków: Universitas, 2004. S. 71-155.

Strasburger, Janusz. Słownik pisarzy nowogreckich. Warszawa: Wiedza Powszechna, 1995.

Tate, Allen. Thomas S. Eliot. The Man and His Works. Londyn: Penguin Books Ltd, 1966.

Tuszyńska, Krystyna. „Konstandinos Kawafis jako poeta modernistyczny”. Miscellanea Novograeca Posnaniensia. Red. K. Tuszyńska. Poznań: Wydawnictwo Naukowe UAM, 2015. S. 21-47.

Vitti, Mario. Historia literatury nowogreckiej. Przeł. Joanna Wegner, Marta Czarnocińska, Katarzyna Rowińska. Warszawa: DiG, 2015. 
Véron, Alain. "Pollutant lead reveals the pre-Hellenistic occupation and ancient growth of Alexandria, Egypt”. Geophysical Research Letters 33 (2006). S. 1-4.

Wawrzyszko, Paweł. „Glossa o architekturze Problematyki modernizmu Richarda Shepparda”. Odkrywanie modernizmu. Przekłady i komentarze. Red. R. Nycz. Kraków: Universitas, 2004. S. 141-154.

Youncenar, Marguerite. Czarny mózg Piranesiego. Wprowadzenie w dzieło Konstandinosa Kawafisa. Przeł. Jan Maria Kłoczowski, Krystyna Dolatowska. Gdańsk: Słowo/Obraz Terytoria, 2004.

\section{| Abstrakt}

Krystyna Tuszyńska, Nina Anna Trzaska

Teoria Poezji Nieosobistej Thomasa Eliota a Kanon Konstandinosa Kawafisa. Porównanie poglądów i założeń dwóch klasycystów

Artykuł ma na celu ukazanie zbieżności poglądów dwóch przedstawicieli modernizmu, Thomasa S. Eliota i Konstandinosa P. Kawafisa. Studium porównawcze poprzedza krótka charakterystyka epoki, pozwalająca wysunąć tezę badawczą: Kawafis mógł wyprzedzić o kilkanaście lat postulaty literackie Eliota. Tekst skupia się na podobieństwie postaw literackich obu autorów, dlatego podstawę analiz stanowi wybrana twórczość eseistyczno-krytyczna Eliota oraz Kanon i pisma teoretyczne Kawafisa. Tekst koncentruje się na następujących aspektach: zestawienie świata przedstawionego Kawafisa z klasycystycznymi poglądami Eliota, omówienie głębszej warstwy założeń literackich obu autorów (porównanie Ars Poetica Kawafisa z Theory of Impersonal Poetry Eliota), spojrzenie na styl Aleksandryjczyka przez pryzmat sądów estetycznych Eliota oraz kwestie związane z procesem twórczym i cechami artysty (dojrzałość i miejsce poety w spektrum homo vates - homo faber).

Słowa kluczowe: modernizm, klasycyzm, eseje Eliota, poezja Kawafisa, Ars poetica, Teoria Poezji Nieosobistej 


\section{| Abstract}

Krystyna Tuszyńska, Nina Anna Trzaska

Thomas Eliot's Impersonal Theory of Poetry and the Canon of Constantine Cavafy. A Comparative Study of Ideas by the Two Classicists

The purpose of this article is to present concurrences in the poetic conceptions of two modernist poets, Thomas Stearns Eliot and Constantine Petru Cavafy. The comparative study is preceded by the brief characteristic of modernism which results in formulation of the following research thesis: Cavafy's work seems to predate Eliot's literary postulates by several years. As the article focuses on similarities in stances of the two authors, the base of the research material consists of selected critical essays by Eliot as well as Canon and theoretical work of Cavafy, known as Ars Poetica. The following issues are featured: analogies between Cavafy's poetry and classicist ideas of Eliot; elaboration on literary premises of the two authors (comparison of Cavafy's Ars Poetica and Eliot's Theory of Impersonal Poetry); reading Cavafy's poems through the perspective of Eliot's aesthetics, work process and characteristic traits of the writer.

Keywords: modernism, classicism, Eliot's essays, poetry of Cavafy, Ars Poetica, impersonal theory of poetry

\section{| Noty o autorach}

Krystyna Tuszyńska - prof. zw. w Katedrze Metodologii Lingwistyki na Wydziale Neofilologii UAM w Poznaniu. Stopień doktora nauk humanistycznych w zakresie filologii klasycznej uzyskała na podstawie rozprawy Filozofia $w$ retoryce Gorgiasza z Leontinoi; tytuł profesora nauk humanistycznych podstawie książki Dyskurs Diona z Prusy w „Mowach o królestwie”. Mariaż retoryki z filozofia, Wydawnictwo Naukowe UAM Poznań 2013. W 2003/2004 uruchomiła na UAM studia neohellenistyczne, jest autorką podręcznika do języka nowogreckiego Pes to sta ellinika. Powiedz to po grecku, Poznań 2006. Przedmiotem jej zainteresowań jest modernizm grecki na tle modernizmu europejskiego. Stypendystka kilku fundacji polskich i zagranicznych: Von Hardt Foundation (Genève- Vandoevres); Institut zur Förderung von Wissenschaftlern und Künstlern aus Ost und Mitteleuropa (Wiedeń); Polskiej Akademii Umiejętności w Krakowie (Londyn, Saloniki), British Council (Cambridge University), wielokrotna stypendystka Summer School of Modern Greek Language and Greek Culture na Uniwersyte- 
cie Arystotelesa w Salonikach oraz na Uniwersytecie w Atenach. Autorka 9 książek, 14 przekładów z języka starogreckiego tekstów z zakresu retoryki i filozofii greckiej z obszernymi wstępami genealogicznymi, ponad 60 artykułów w języku polskim i angielskim. Członek Athens Institute for Education and Research (ATINER) w Literature Unit i Philosophy Unit; członek Polskiego Towarzystwa Filologicznego oraz wice-prezes Polskiego Towarzystwa Studiów Nowogreckich. E-mail: krystusz@interia.pl; krysmac@amu.edu.pl

Nina Trzaska - mgr, licencjat na Wydziale Artes Liberales w Warszawie, stopień magistra filologii nowogreckiej na Wydziale Neofilologii UAM, w przygotowaniu dysertacja doktorska w zakresie literaturoznawstwa greckiego. Autorka przekładu na język polski powieści Morderczyni Aleksandrosa Papadiamantisa (w „Arcydziełach Literatury Nowogreckiej”). Autorka 7 publikacji w czasopismach i monografiach polskich. Uczestniczka międzynarodowych konferencji naukowych w Atenach, Lund, Braszowie, Poznaniu i Wrocławiu. Wykładowca na Wydziale Neofilologii UAm w Poznaniu. Do jej zainteresowań badawczych należą: literatura grecka, przekład literacki, folklor grecki (w szczególności problematyka wampiryzmu).

E-mail: nintrz@amu.edu.pl 